\title{
THRIPS INJURY TO PEACHES IN SOUTHERN CALIFORNIA
}

\author{
By Geo. P. Weldon, Pomologist, \\ Chaffey Junior College of Agriculture, Ontario, Calif.
}

In the fall of 1914 some Elberta peaches were received at the office of the State Commissioner of Horticulture, Sacramento, from Placer County. These peaches showed a type of injury which at that time was not recognized as being due to insects. A number of growers in the vicinity of Auburn and New Castle were complaining of damaged peaches which were noticed at the time the fruit was being packed. It was not until the next season that this injury was found to be due to the attack of some species of thrips. County Farm Advisor E. O. Amundson, in examining the blossoms of peaches early in the spring of the year, found that they were full of thrips. He later made observations which showed conclusively that the injury which had been observed commonly the previous season was due to this little insect.

No data is at hand which would enable one to make an estimate of the injury which was done during the years 1914 and 1915 in Placer County, however, it is known that in some sections severe damage resulted from the attack of this insect.

In August of 1919 the writer moved to Southern California taking up work with the Chaffey Junior College of Agriculture. It was found in looking over peaches that were coming into local canneries at Ontario that quite a large percentage of them showed injury similar to that which had been noted in Placer County. Estimates were made of the percentage of fruit which had the distinct marks of thrips and it was decided that at least twenty-five percent of all the fruit which was handled by two large local canneries showed marked infestation. Most of the growers and men associated with the canneries were undecided as to what had caused the injury. A few of the older growers however, recognized the fact that thrips were responsible for this injury as from time to time in past years they had suffered losses from it.

In 1920 the writer had an opportunity to make more extensive observations than previously; these during a year when the pest was worse than it had ever been known in the history of peach growing in Southern California. The loss, while it could not be estimated accurately during this season, would represent a large sum of money. It was: estimated by careful observations in the field and of the fruit as it came into the canneries that more than fifty percent showed injury 
from thrips. While this injury does not render the peaches valueless, many of them are culls that must be canned as very low grade fruit, while none of them can be packed in the higher grades.

\section{LifE History}

While it was not possible to make careful enough life history studies of the pest to enable one to conclude definitely as to where it spends the winter season, etc., it was found that as soon as the peaches began to bloom in the spring adult thrips immediately got into the blossom where egg laying took place and where feeding was done by both a'dults and larvae.

Throughout the time of blooming of the peaches and later until the time when the husk shed from the little.peach the injury continued. Practically no injury was done after the shedding of the husk. The very uneven blooming season during 1920 made it difficult to get any results whatsoever with a contact spray. Various things were tried but with no success as will be indicated later. The blooming period lasted approximately two to three months, according to the variety and all this time as the trees were coming into bloom, thrips were going into the blossoms.

After the peaches had attained considerable size many thrips were found in the tender growth at the tips of the twigs. In fact, throughout the entire summer season some of them could be found in such places but none on the fruit for any length of time after the shedding of the husk. The injury therefore, by this species, was found to be done while the trees were in bloom and afterwards up to the time of the shedding of the husks.

\section{Demonstrations}

A series of demonstrations were planned during the season of 1920 which were designed to give the growers an idea as to how the pest might be controlled. It had been claimed by those who had worked on the pest in Placer County that a thorough spraying while the peaches were in bloom, or a little later, with Nicotine Sulfate Distillate Emulsion mixture which is so successfully used in pear thrips control, would bring results. After one or two demonstrations had been conducted it was determined that so small a percentage of the thrips was being killed that the spraying was not paying for itself. Careful observations of the insect in treated blossoms led to the belief that not over fifty percent were killed by a single application of the Nicotine Sulfate Distillate Emulsion mixture. It must not be understood from this that the mixture did not kill for it was found that where it was 
possible to get the spray on the thrips, that there was no trouble in killing them. The difficulty lay in being able to get the spray into the blossoms and later under the husks of the little peaches.

Various types of nozzle were used and as high pressure as was possible to obtain with a power sprayer was tried in an effort to get the spray where the thrips were protected by the blossoms or the husks. In all the work the fact was apparent that the protection of the stamen bars and the pistil of the peach blossom was such that it was almost impossible to reach the insects with the spray and after the peaches had formed the same difficulty was experienced in getting the spray beneath the driedup blossom or husk. Thus, after recommendations had been made regarding the way this insect might be controlled, spraying was stopped in orchards of the community because of failure to get the desired results.

\section{Dusting}

Samples of Nicodust manufactured by the California Walnut Growers Exchange were also used in some experiments. Regular strength of this material as well as double strength; also a Nicodust material made from nicotine and sulphur, were all tried but none of them were successful. Blossoms that were thoroughly coated with these dust materials were brought into the laboratory and in twenty-four hours' time it was found that the thrips were apparently just as lively as before the material was applied. A few thrips seemed to be killed where the dust came in actual contact with them but where it did not, there seemed to be no effect from fumes and thrips inside of blossoms where the stamen bars and pistil were heavily coated with this material were as lively as ever.

In 1921 the dusting experiments were repeated although it was not possible during this season to find as bad an infestation as most of the orchards had the previous season. The same negative results were secured in 1921 as in 1920.

\section{INJURY}

The characteristic injury done to peaches by thrips assumes a number of different forms which seem to be influenced somewhat by the variety.

In the case of Phillips Cling variety for example, a very common type of injury is a little conical shaped swelling on the surface of the fruit. In the case of the Tuskena variety the injury that is more commonly noticed consists of a pitting or dimpling of the surface of the fruit. In other cases where the fuzz has been removed entirely by the thrips in feeding, the skin will be colored a deep red and will be smooth like the 
skin of the nectarine. Wavy red lines are commonly seen on such varieties as Lovell, while russet or scabby patches and streaks may be found on practically all varieties where injury has taken place.

This injury, while as has already been stated, does not seriously impair the quality of the peach, makes it very difficult to remove the peel when the fruit is being canned. In the modern commercial canneries the peaches are peeled by means of lye and it was found that the lye bath did not successfully remove the skin from thrips injured peaches, thus necessitating hand trimming of the portions of the fruit affected, which is slow and expensive.

\section{OTHER Hosts}

Not only is the species of thrips which is found injuring peaches injurious to this fruit, but it is also very commonly found on plums, apricots and nectarines. In the case of the nectarine the injury is more severe than with any other fruit where the pest has been seen. Plums are frequently badly injured while apricots are injured to a lesser extent. The Royal variety which is more commonly grown in California than any other variety of apricot, does not seem to be so susceptible to attack as the Tilton variety, another commercial sort which is commonly grown. Wherever the latter variety has been observed, large numbers of thrips. have been found feeding upon it.

A species that may be identical with the peach species has been found feeding on apples in the Yucaipa section of San Bernardino County. During the season of 1920 there were large numbers of thrips in the blossoms of the apple but the injury did not seem to be great.

\section{Seasonal Occurrences}

Fortunately the thrips pest seems to vary greatly in its attack from season to season. As has already been stated during the season of 1919 and 1920 the injury in the Ontario-Cucamonga-Pomona section of Southern California, was very severe. This year, 1921, the injury was slight and in the spring it was rather difficult to find orchards where there were enough thrips to make experimental work worth while. Then too, the blooming season of peaches in 1921 extended over a much shorter period than the previous season. This factor in itself bears a very close relation to the damage done by the insect for when there is a long blooming period there is a correspondingly long time for the insects tofeed in the blossom a nd under the husks which of course, means far greater injury. While the blooming season in 1920 as has been stated, was from two to three months, in 1921 peaches were through blooming in practically one month's time. 


\section{Species}

Nothing has been said that would indicate what species of thrips is responsible for the injury to peaches that has been described in this paper. At the present time a positive determination has not been made. The species very closely resembles the grain thrips, Euthrips tritici but some thrips experts who have examined material doubt that it is this species. There is a possibility of its being Euthrips helianthi according to Morgan of the U. S. Bureau of Entomology. Paul Jones, Entomologist for Balfour, Guthrie \& Company, San Francisco, who has examined material, thinks that the species is Euthrips tritici, although he is not positive that it is. The writer inclines to the belief that Euthrips helianthi is the species which we have been dealing with in our peach orchards. It is a species that is very commonly found on sunflowers and last fall in fields where there were hundreds of acres of sunflowers in bloom, thrips occurred in large numbers in every blossom. It however, seems to be a general feeder and may be found in the blossom of alfalfa, Burr clover, Melilotus, mustard, and various other flowering plants.

The great damage which has been done during certain seasons by this species in both the Northern part of the state and the Southern deciduous fruit growing section, makes it a pest of first importance. The injury to peaches as it occurred in 1920 in the Ontario section is comparable to that of pears by pear thrips during a season of bad infestation. It is therefore important that some careful work be done on this insect to determine the species, its life habits and methods of control. At the present time we are not justified in stating that the ordinary methods which are used in the control of pear thrips will be a success in the control of peach thrips because the pest is so well protected during the entire time of its feeding on peaches.

\section{THE RESULTS OF USING CERTAIN OIL SPRAYS FOR THE CONTROL OF THE FRUIT TREE LEAF-ROLLER ${ }^{1}$ IN THE PAJARO VALLEY, CALIFORNIA}

- By Donald D. Penny, Watsonville, Calif.

The fruit tree leaf-roller, in the Watsonville ${ }^{2}$ apple district, continues each season to damage a certain amount of the fruit crop and while the infestation has never become such a serious menace as has been reported from some sections of the West, this insect does, however, do enough injury to render it a pest worthy of considerable attention.

\footnotetext{
${ }^{1}$ Archips argyrospila Walker.

2The city of Watsonville, California, is located on the coast about one hundred miles south of San Francisco, in the center of the Pajaro Valley. This valley contains approximately nineteen thousand acres of bearing apple orchards.
} 